\title{
Lupin Blue is Promising Raw Material for Food Production
}

\author{
I.A. Pankina \\ Graduate School of Biotechnology and Food Science \\ Peter the Great St. Petersburg Polytechnic University \\ Saint-Petersburg, Russia \\ pankina_ilona@mail.ru
}

\section{A.D. Sevastyanova}

Graduate School of Biotechnology and Food Science

Peter the Great St. Petersburg Polytechnic University

Saint-Petersburg, Russia

anna-julija@rambler.ru

\author{
E.S. Belokurova \\ Graduate School of Biotechnology and Food Science \\ Peter the Great St. Petersburg Polytechnic University \\ Saint-Petersburg, Russia \\ oldseadog@inbox.ru
}

\author{
A.N. Shlykova \\ Graduate School of Biotechnology and Food Science \\ Peter the Great St. Petersburg Polytechnic University \\ Saint-Petersburg, Russia \\ shantonina@inbox.ru
}

\begin{abstract}
This article is devoted to one of the world's major nutritional problems, which is associated with a lack of protein and its imbalance in the diet of people. Nowadays this problem is particularly associated with the reduction in the consumption of animal products in our country. The main focus in solving this nutritional problem is the search for promising sources of dietary protein.

Creation of new food products from natural raw materials is very perspective. Numerous studies of the chemical composition of legumes have shown that they are promising to fill the deficit of most of the vital components of food, including protein. Special attention is attracted by the culture of narrow-leaf lupine, which is considered as high-protein culture. The article presents the results of the research of the amino acid composition of lupine seeds of the "Snowball" variety of domestic selection. These results showed that lupine seed proteins are high-grade proteins.

They are distinguished by a high content of essential amino acids (more than $\mathbf{3 8 \%}$ ), as well as a low content of alkaloids (not more than $0.04 \%$ ). This facts allow us to recommend the use of lupine seeds of this variety to create new types of food.
\end{abstract}

Keywords -lupin blue, proteins, amino acids, food.

\section{INTRODUCTION}

At the present stage of development of the agricultural complex and the food biotechnology industry in Russia, special attention is paid to the efficient use of renewable natural resources in our country. The most relevant researches are the researches of ecologically safe alternative sources of raw materials for the production of food products with biologically active properties.

Providing the population with inexpensive and high-quality food products is especially important due to the fact that a decrease in household incomes significantly reduces the amount of the most biologically valuable food products, mainly protein foods [1].

More than $10^{5}$ different protein molecules are contained in the human body. One of the most important functions of proteins is their participation in regulatory mechanisms of the body, which controls the work of endocrine organs, gastrointestinal tract, liver, bone marrow [16].

Sources of high-grade protein, containing a complete set of essential amino acids in an amount sufficient for protein biosynthesis in the human body, are products of animal origin. These proteins are almost completely assimilated by the human body by $93-96 \%$ [13].

The physiological need for protein depends on age, gender and physical activity. According to the calculations of the Russian Academy of Medical Sciences specialists, daily essential protein consumption (average) for the adult population is from 65 to $117 \mathrm{~g}$ / day for men and from 58 to $87 \mathrm{~g} /$ day for women.

In addition to proteins of animal origin, food production also includes the use of proteins of vegetable origin, but their set of essential amino acids is much worse and lower than proteins of animal origin. In addition, some plants contain various inhibitors that interfere with protein assimilation, therefore vegetable protein is assimilated by the human body much worse - only by $62-80 \%$. [13]. For example, legumes contain proteinase inhibitors, which reduces the assimilation of their protein.

At the same time, it is known that from 3 to 7 units of vegetable protein are needed to produce 1 unit of animal protein, therefore, according to various studies, the protein deficiency in feed is currently $20-25 \%$.

The structure of vegetable protein fund is dominated by proteins of cereal crops; nevertheless, the ratio of proteins of leguminous crops is about $1 / 3$ of the total world vegetable protein production. The leguminous plants contain a lot of protein $(20-40 \%)$ due to symbiosis with nodule bacteria. 
Figure 1 shows the averaged data on protein content in various grain legumes $[13,16]$.

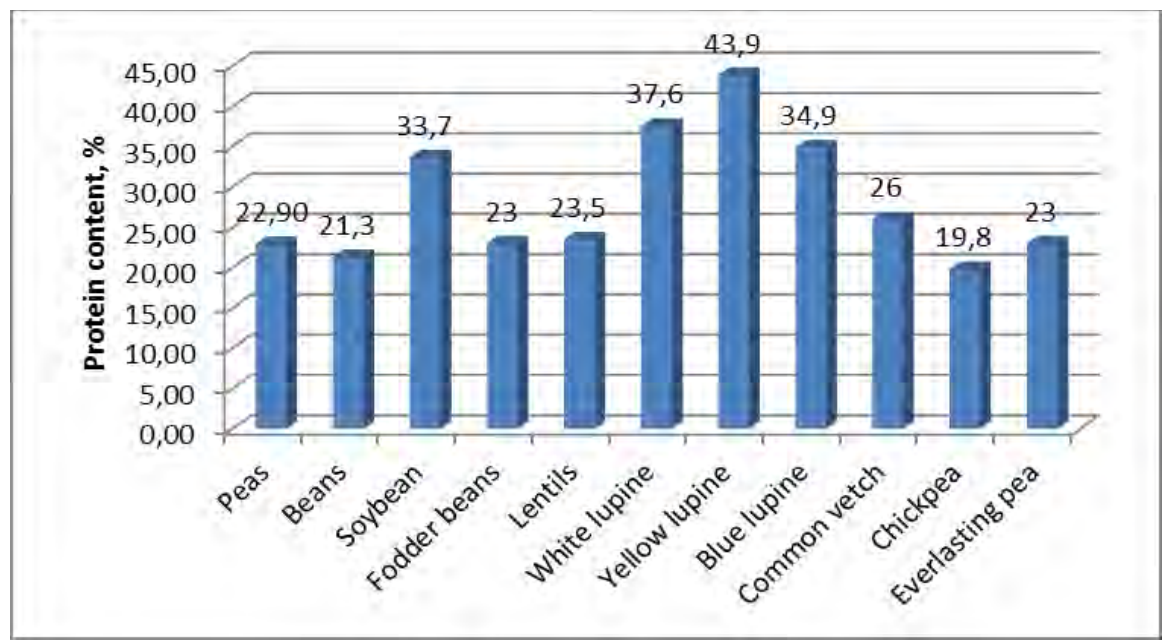

Fig. 1. Protein content (\%) in legumes

Soybean and lupine are the only two crops that can solve the problem of providing the livestock sector with feed. These legumes synthesize and accumulate protein more than all grains [24]. This fact is explained by the presence of symbiotic nitrogen-fixing microorganisms on the roots of these plants, which fix nitrogen from the air and synthesize high-molecular nitrogen-containing compounds with it.

In current established economic conditions, lupine is the most affordable, economically profitable and ecologically safe feed for the livestock industry. At present, narrow-leaved lupine has become widespread in our country $[2,6,14]$. Currently AllRussian Research Institute of Lupine, Laboratory of Leguminous Crops Selection of the State Research Institute of Scientific Research and Development, Department of Plant Industry of the TSHA are conducting a massive research project on breeding new varieties of lupine. This culture is considered valuable for farmers, because it is capable of yielding high harvests annually without fertilizers application on practically any soils. It means a cheap high-quality protein for animal husbandry.

One more beneficial feature of the narrow-leaved lupine lies in their relative toleration of low temperatures. Growing plants of the narrow-leaved lupine can withstand the temperature drop down to $-9{ }^{\circ} \mathrm{C}$. Therefore, from the point of cultivation regions, the narrow-leafed Lupine is mostly spread across the northern regions of the Nonblack-earth soil zone of the Russian Federation. Cultivation of this crop for feed purposes is being actively introduced into the practice of agricultural production. One of the main advantages of this legume is the protein content, which reaches $40-50 \%$ in grain.

According to Gomes E.F (1994), assimilation of nitrogenous compounds from lupine seeds in the animal body is comparable to assimilation of fishmeal and is $85.50 \%$, while for fishmeal it amounts to $86.60 \%$. Assimilation percentage of pea protein compounds is 80.40 , whereas meat meal -90.80 . However, advanced use of lupine for feed and food purposes is limited due to the presence of alkaloids in it.
Breeding of new varieties of narrow-leaved lupine plants with a low content of alkaloids will allow one to use it not only as animal feed, but also in food production $[9,10,15,19]$.<smiles>CC1CCCC2CCCCC12</smiles>

a<smiles>O=C1CCCCC12CC1CC3CCCCC3C2C1</smiles>

$\mathrm{b}$<smiles>O=C1CCCCC12CC1CC2CC2CCCCC21</smiles>

$\mathrm{c}$

The structure of the lupine alcoloids ( $\mathrm{a}$ - Lupinine; $\mathrm{b}$ - Lupanine; c - Sparteine) 
Alkaloids are a special group of natural biologically active organic substances of the secondary metabolism, mainly of plant origin, containing nitrogen in their structure. Usually the content of alkaloids in plants is small. Alkaloids have alkaline properties and form salts in combination with acids. They are present in the form of salts of mineral acids, more often carboxylic acids (malic, oxalic, acetic, citric) in plants. Most alkaloids have a bitter taste. The basis of the structure of alkaloid molecules is the heterocycle of the pyrrolidine nucleus, pyridine, imidazole, purine, etc. $[7,8,11]$.

Lupine alkaloids have the following structure shown in Figure 2 [20].

All lupine alkaloids have a bitter taste. The more alkaloids in plants, the more bitterness in them. Like other alkaloids, lupine alkaloids exhibit the properties of bases, which are due to the nitrogen atoms that make up their molecules. As bases, lupine alkaloids dissolve well in many organic solvents, for example, in chloroform and ether, and form salts with acids. Alkaloid salts are soluble in water and poorly soluble in organic solvents. Therefore, when choosing methods for extracting alkaloids from plant raw materials, these features are taken into account [3].

Lupine alkaloids are poisonous to human and animals. Their small amounts do not have a harmful effect on the body, but large amounts cause illness and even death. In this regard, it is necessary to check the content of alkaloids in lupine seeds used in the technology of production dietary protein [23].

Varieties of lupine, containing less than $0.02 \%$ of alcaloids were bred as a result of the selection of varieties of lupine and the strict control over the content of alkaloids in lupine plants. According to the data of the All-Russian Scientific Research Institute of Lupine (2001), different varieties, depending on the content of alkaloids in the seeds, have different uses that is indicated in Table 1 [5].

TABLE I. APPOINTMENT OF LUPINE GRAIN DEPENDING ON THE CONTENT OF ALKALOIDS

\begin{tabular}{|c|c|c|}
\hline Group & $\begin{array}{c}\text { The content of alkaloids } \\
\text { in lupine seeds, } \\
\text { \% dry matter }\end{array}$ & Use \\
\hline 1 & Very low $<0.025$ & Food sweet \\
\hline 2 & Low $0.025 \div 0.099$ & Low alkaloid \\
\hline 3 & Average $0.100 \div 0.299$ & $\begin{array}{c}\text { Stern medium } \\
\text { alkaloid }\end{array}$ \\
\hline 4 & High $0.300 \div 1.000$ & Sideral bitter \\
\hline 5 & Very high $1.001 \div 3.500$ & Wild growing \\
\hline
\end{tabular}

The lupine variety "Snezhet" was bred as a result of the creation of lupine varieties with a lower content of alkaloids.

Narrow-leaved Snezhet lupine (Lupinus angustifolius L.) is a variety of universal usage. This botanical sort was included in the State Register in 2002 for the Central, North-Western, Volga-Vyatka and Ural regions of the Russian Federation. This variety is characterized by a consistently low content of alkaloids in seeds (0.03-0.04\%). Nutritional and antinutrient factors of the narrow-leaved lupine of Snezhet variety (according to T. Lenkova and V. Zevakova) are presented in Table 2.

In the practice of forage production, lupine, which seeds contain less than $0.025 \%$ of alkaloids, is classified as a sweet sort, and can be used for food purposes [22,25]. The purpose of this work was to study biological value of the protein complex of narrow-leaved lupine (L. angustifolius L.) seeds of domestic selection.

TABLE II. NUTRITION AND ANTI-NUTRITIONAL FACTORS OF NARROWLEAVED LUPINE SNEZHET

\begin{tabular}{|l|c|}
\hline \multicolumn{1}{|c|}{ Nutritional values, \% } & Snezhet \\
\hline Alkaloid & 0.025 \\
\hline Crude protein & 29.03 \\
\hline Raw fiber & 15.19 \\
\hline Crude Fat & 5.71 \\
\hline Lysine & 1.26 \\
\hline Valine & 1.22 \\
\hline Methionine & 0.62 \\
\hline Isoleucine & 1.32 \\
\hline Leucine & 2.54 \\
\hline Threonine & 1.35 \\
\hline Protein digestibility within 3 hours & 69.4 \\
\hline The content of trypsin inhibitor & 0.018 \\
\hline Mass fraction of tannin (tannin) & 0.22 \\
\hline
\end{tabular}

\section{OBJECTS AND METHODS OF RESEARCH}

An analysis of literature data showed that low-alkaloid varieties of lupine, which have been bred relatively recently, have not been fully studied [1]. In this work, studies were carried out on lupine seeds of the narrow-leaved variety "Snezhet", obtained from the VNII Lupine (Bryansk). This sample was grown in the Nonblack-earth soil zone of the Russian Federation. To determine the amino acid composition of lupine seeds, the method of high-speed liquid chromatography of proteins (SLC) was used. This method has been widely used in studies of biopolymers. Liquid chromatography is a method of separation and analysis of complex mixtures in which the mobile phase is liquid. Analysis of the amino acid composition of lupine seeds was performed on a high-speed automatic amino acid analyzers JLC-02 from JEOL (Japan). According to the principle of operation this analyzer is a universal liquid chromatograph capable of creating a gradient elution with a mobile phase, which ensures the separation of the analyzed amino acids on a chromatographic column. The study included acid hydrolysis of protein in $\mathrm{HCl}$ at $110{ }^{\circ} \mathrm{C}$ in a nitrogen atmosphere for 24 hours with betamercaptoethanol, beta-thiodiglycol to prevent degradation of sulfur-containing amino acids.

\section{RESULTS AND DISCUSSIONS}

In the grain of lupine narrow-leaved variety "Snezhet", protein content amounts to $39.2 \%$. This allows one to attribute it to high-protein seeds $[4,12,17,18]$. However, food containing even a significant amount of protein may be incomplete if these proteins do not have the necessary set of essential amino acids. Amino acids serve not only as a source of formation of substances necessary for life activities - proteins, peptides, 
enzymes, hormones, etc., but also are the final products of nitrogen metabolism - ammonia, urea, etc. Amino acids have antioxidant properties. Amino acids are endogenous sorbents that carry out direct transport of most active compounds (minerals, vitamins, hormones, etc.). Essential amino acids must necessarily come with food, their deficiency can not be covered by other protein amino acids.

The results of the amino acid composition of "Snezhet" variety lupine grain are given in Table 3 .

TABLE III. AMINO ACID COMPOSITION OF LUPINE GRAIN OF SNEZHET VARIETY

\begin{tabular}{|c|c|c|}
\hline Amino acids & $\%$ of protein & $\mathrm{g} / 100 \mathrm{~g}$ of grain \\
\hline \multicolumn{3}{|c|}{ Essential amino acids: } \\
\hline Isoleucine & 4.31 & $1.69 \pm 0.08$ \\
\hline Valine & 5.10 & $1.99 \pm 0.06$ \\
\hline Leucine & 8.20 & $3.21 \pm 0.08$ \\
\hline Lysine & 6.20 & $2.43 \pm 0.07$ \\
\hline Methionine + cystine & 2.10 & $0.82 \pm 0.03$ \\
\hline Threonine & 3.80 & $1.49 \pm 0.03$ \\
\hline Phenylalanine + tyrosine & 8.54 & $3.35 \pm 0.07$ \\
\hline Tryptophan & 1.00 & $0.39 \pm 0.01$ \\
\hline Amount & 38.95 & $15.39 \pm 0.05$ \\
\hline \multicolumn{3}{|c|}{ Replaceable amino acids: } \\
\hline Alanine & 3.00 & $1.18 \pm 0.04$ \\
\hline Arginine & 10.73 & $4.21 \pm 0.09$ \\
\hline Histidine & 3.60 & $1.41 \pm 0.02$ \\
\hline Proline & 4.27 & $1.67 \pm 0.08$ \\
\hline Amount & 21.60 & $8.47 \pm 0.05$ \\
\hline
\end{tabular}

Analysis of the amino acid composition shows that the proteins of the studied legume seeds are rich in lysine and other essential amino acids. Thus, the content of essential amino acids in the grain of lupine of "Snezhet" variety is more than $38 \%$ of the protein.

Figure 3 shows the standard scale for the ideal protein recommended by the joint $\mathrm{FAO} / \mathrm{WHO}$ committee $[13,21]$ and amino acid score of proteins of the investigated grade of lupine grain.

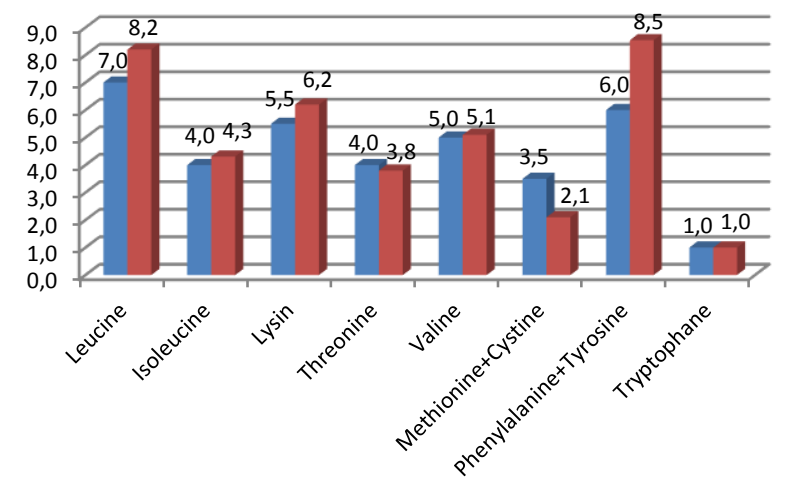

Fig. 2. Comparative content of essential amino acids in the grain of lupine of "Snezhet" variety with the FAO/WHO standard: (blue - The content of amino acids on the FAO / WHO scale, red - The content of amino acids in the sample)
The results of the conducted studies show that the amino acid composition of lupine proteins is close to ideal, except for sulfur-containing amino acids. This way, the amount of amino acid methionine + cystine is $60 \%$, and threonine is $95 \%$. In relation to the $\mathrm{FAO} / \mathrm{WHO}$ standard, the lysine content is $113 \%$, isoleucine $-108 \%$, leucine $-117 \%$, the amount of tyrosine + phenylalanine $-142 \%$.

\section{CONCLUSIONS}

According to the results of studies of the biological value of L. angustifolius lupine grain of the "Snezhet" variety, it can be concluded that it is expedient to increase the production of seeds of this variety of lupine with the prospect of using them in food technology and creating new types of food products.

A promising direction is the development of biotechnological processes for the production of protein preparations from plants with modified functional and technological properties in accordance with the requirements of specific food technologies [1]

The amino acid composition of the investigated narrow-leaf lupine is close to ideal, except for sulfur-containing amino acids. The high content of essential amino acids in the protein (more than 38\%) suggests that the proteins of the investigated lupine seeds are complete and can be used to meet the physiological needs of human for nutrients and energy along with animal proteins.

Therefore, we can say with confidence that the non-alkaloid varieties of narrow-leaved, white and yellow lupine created in recent years can be considered as valuable protein and fatcontaining raw materials for obtaining new types of food protein products. However, at this stage of development of crop production and processing industry, the potential for using lupine in our country is far from optimal, so it is advisable to continue scientific development in this direction.

\section{References}

[1] P.A Ageeva, S.N Borisova, Zh.V. Tsarapneva \& N.A. Pochutina, "Results and prospects of selection of narrow-leaved lupine" Forage production, vol.1, pp. 13-16, 2001.

[2] N.V. Andreev, "Lupine is a multi-purpose raw material for the food processing industry". Theses of reports. International Scientific and Practical Conference, St. Petersburg, pp. 75-76, 1996.

[3] D. Ballester, E. Yanez, R. Garcia, S. Erazo, F. Lopez, E. Haardt, S. Cornejo, A. Lopez, J. Pikniak \& C. O. Chichester "Chemical Composition, Nutritive Value, and Toxicological Evaluation of Two Species of Sweet Lupine (Lupinus albus and L. luteus)", Agriculture and Food Chemistry, pp. 402-405, 1980.

[4] L.M. Borisova, I.A. Pankina, "The use of lupine grain for the creation of functional and therapeutic and prophylactic food products", Innovative technologies: priority directions of development. International scientific and practical Internet conference, pp. 161-165, April 2011 [pp. 161-165, 2011].

[5] T.F. Demyanenko, M.L. Domoroshchenkova, "The technology of obtaining food dispersions from the seeds of lupine and soy", Theses of reports. International Scientific and Practical Conference, pp. 81-82, October 1996 [Lupin and amaranth-sources of new food and dietary products, p. 102, 1996].

[6] M.L. Domoroshchenkova, "Modern trends in the development of technologies and the market of food soy proteins", Grain and Bread of Russia, p. 101, November 2007 [III International. Congress, p. 120, 2007]. 
[7] M. Erbas, M. Certel, M.K. Uslu, "Some chemical properties of white lupin seeds (Lupinus albus L.)", Food chemistry, p. 89, 2005.

[8] G.G. Filiptsova, I.I. Smolich, Fundamentals of plant biochemistry: a course of lectures, Minsk, 2004, pp. 28-33.

[9] V. Jayasena, K. Quail, "Lupin: A Legume with A Future", Food and Beverage Asia, vol. 12, pp. 16-22, 2004

[10] V.V. Klyuchkin, "The main directions of processing and use of food products from the seeds of lupine and amaranth", Theses of reports. International Scientific and Practical Conference, pp. 65-73, October 1996 [Lupin and amaranth-sources of new food and dietary products, $\mathrm{p}$. 102, 1996].

[11] L.V. Kovalenko, Biochemical bases of chemistry of biologically active substances: a tutorial, Moscow, 2012, pp. 56-68.

[12] V.N. Krasilnikov, I.A. Pankina, "Investigation of the chemical composition and technological properties of lupine narrow-leaved seeds for the purpose of creating combined food products", "Problems of deficiency of vegetable protein and ways to overcome it", pp. 119-122, July 2006, [International Conference, p. 430, 2006].

[13] I.F. Kryuk, Biochemistry and Commodity Research of seeds of leguminous crops and products of their processing, Minsk, 1961, pp. 9195.

[14] A.N. Lisitsin, V.V. Klyuchkin, V.N. Grigorieva, "Lupine as a component of food and diet products", Forage production, vol. 1, pp. 31-32, 2001.

[15] R.J. Lowen, F.A. Alam, J.A. "Edgar Lupins bean toxicity", The Medical Journal of Australia, vol. 162, pp. 256-257, 1995.

[16] A.V. Mironenko, Physiology and biochemistry of lupine, Minsk, 1965, pp. $47-52$.

[17] I.A. Pankina, L.M. Borisova, E.S. Belokurova, "Investigation of physical and technological properties of seeds of leguminous crops", Grain economy of Russia, vol. 2, pp. 34-37, 2015.
[18] I.A. Pankina, L.M Borisova, "Perspective directions of using narrowleaved lupine and investigating the rheological properties of protein paste on it's basis", The consumer market of Eurasia: the current state, theory and practice in the conditions of the Customs Union and the WTO, pp. 123-127, March 2015 [II International Correspondence Scientific and Practical Conference, p. 288, 2015].

[19] D.S. Petterson, "Is there a role for lupins in human nutrition?", Proceedings of the Australian Cereals Chemistry Conference, September [45th Conference, p. 564, 1995].

[20] D.S. Petterson, Composition and food uses of lupins. Lupins as Crop Plants; Biology, Production and Utilisation, 1998, pp. 353-384.

[21] A.S. Ratushniy, V.I. Hlebnikov, B.A. Baranov, Technology of production of public nutrition: in 2 volumes, vol.1-2, Moscow, 2003

[22] A. Skarafoni, A. D. Cataldo, C. Magni, M. Duranti, "Lupin Seeds as a Sourse of Nutraceuticals", Wild and Cultivated Lupins from the Tropics to Iceland, pp. 352-354, June 2002 [10th international Lupin Conference, 2002]

[23] M. Stobiecki, B. Blaszczyk, S.H. Kowalczyk-Bronisz, K. Gulewicz The "Toxicity of Seed Extracts and their Fractions from Lupinus angustifolius and L. albus", Journal of Applied Toxicology, vol. 13(5), pp. 347-352, 1993.

[24] M.A. Vishnyakova, "Economic and breeding potential of grain legumes", Grain and Bread of Russia, p. 106, November 2005 [I International. Congress, p. 128, 2005]

[25] Von Baer E., Vath D., "New varieties of lupin", VI Intern. Lupin Conf., pp. 376-381, November 1990 [VI international Lupin Conference, 1990]. 